\title{
Posiedzenie Rady Europejskiej w dniach 14-15 marca 2013 r. w Brukseli. Konkluzje
}

W ostatnich latach uczyniliśmy wiele, aby stawić czola pilnym wyzwaniom wynikajacym z kryzysu finansowego i zadtuzeniowego, majac na celu przygotowanie gruntu dla powrotu do trwatego wzrostu sprzyjajacego tworzeniu miejsc pracy i przejście do wzmocnionego zarzadzania gospodarczego zarówno na szczeblu UE, jak i strefy euro. Wiele zostało osiagnięte pomimo pewnej utrzymujacej się niepewności na rynkach finansowych. Niemniej jednak stagnacja dziatalności gospodarczej przewidywana na rok 2013 oraz niedopuszczalnie wysokie wskaźniki bezrobocia uwydatniaja, jak ważne jest przyspieszenie dziatań wspierajacych wzrost gospodarczy na zasadzie priorytetu przy kontynuacji prowzrostowej konsolidacji fiskalnej. Rada Europejska przeprowadzila kompleksowa dyskusję na temat sytuacji gospodarczej i społecznej oraz określiła wytyczne dotyczace polityki gospodarczej państw czlonkowskich i Unii Europejskiej w 2013 roku. Trzeba się skoncentrować na wykonaniu podjętych decyzji, w szczególności jeśli chodzi o Pakt na rzecz wzrostu gospodarczego i zatrudnienia. Jako szczególnie priorytetowe należy potraktować kwestie wspierania zatrudnienia młodzieży oraz stymulowania wzrostu gospodarczego i konkurencyjności. Rada Europejska w czerwcu ponownie zajmie się ocenq określanych na szczeblu krajowym strategii stużacych realizacji tych priorytetów; wróci również do kwestii realizacji Paktu na rzecz wzrostu gospodarczego i zatrudnienia. Uzgodniła, ze w nadchodzacych miesiacach będzie omawiać konkretne dziedziny majace znaczny wptyw na zwiększenie wzrostu i zatrudnienia. Podsumowata takze trwajace prace nad pogtebieniem unii gospodarczej $i$ walutowej (UGW) z myślq o swoim czerwcowym posiedzeniu.

\section{POLITYKA GOSPODARCZA I SPOLECZNA}

\section{Europejski semestr: wspieranie konkurencyjności, wzrostu i zatrudnienia, w szczególności ludzi młodych}

1. Jak uzgodniono w grudniu ubiegłego roku, państwa członkowskie i Unia Europejska podejmują zdecydowane działania na rzecz wspierania konkurencyjności, wzrostu i zatrudnienia, zgodnie $\mathrm{z}$ następującymi priorytetami określonymi w rocznej analizie wzrostu gospodarczego:

a) kontynuacja zróżnicowanej konsolidacji fiskalnej sprzyjającej wzrostowi gospodarczemu;

b) przywrócenie normalnego kredytowania gospodarki;

c) wspieranie wzrostu gospodarczego i konkurencyjności;

d) walka z bezrobociem i społecznymi konsekwencjami kryzysu;

e) unowocześnienie administracji publicznej. 
2. Kluczowe znaczenie nadal ma realizacja. Niezbędne są zdecydowane działania, by wesprzeć stanowcze zobowiązanie polityczne na rzecz wspierania wzrostu i zatrudnienia, a także by odpowiedzieć na wyzwania fiskalne, makroekonomiczne i strukturalne. Wszystkie te elementy powinny znaleźć odzwierciedlenie w przygotowywanych przez państwa członkowskie krajowych programach reform oraz programach stabilności i programach konwergencji, z pełnym uwzględnieniem dyskusji, które były prowadzone na forum Rady - w kontekście europejskiego semestru - na temat przygotowanej przez Komisję rocznej analizy wzrostu gospodarczego, zgodnie ze sprawozdaniem podsumowującym prezydencji oraz odpowiednimi konkluzjami Rady ${ }^{1}$, a także analizy przekazanej przez Komisję w kontekście procedury dotyczącej zakłóceń równowagi makroekonomicznej, w tym sprawozdaniem przedkładanym w ramach mechanizmu ostrzegania.

3. Czynione są znaczne postępy w dążeniu do strukturalnie zrównoważonych budżetów; postępy te muszą być kontynuowane. Rada Europejska podkreśla w szczególności konieczność zróżnicowanej konsolidacji fiskalnej sprzyjającej wzrostowi, przypominając o możliwościach, jakie dają istniejące zasady fiskalne zawarte w pakcie stabilności i wzrostu oraz traktacie o stabilności, koordynacji i zarządzaniu.

4. Na szczeblu państw członkowskich należy zastosować odpowiednią kombinację środków w zakresie wydatków i dochodów, w tym krótkoterminowych ukierunkowanych środków na rzecz pobudzenia wzrostu i wspierania tworzenia miejsc pracy, zwłaszcza dla ludzi młodych; należy też priorytetowo traktować inwestycje sprzyjające wzrostowi. W zwiazku z tym Rada Europejska przypomina, że - przy pełnym poszanowaniu paktu stabilności i wzrostu - możliwości, jakie istniejące unijne ramy fiskalne dają w kontekście godzenia potrzeb w zakresie produkcyjnych inwestycji publicznych z celami dyscypliny fiskalnej, mogą być wykorzystane w ramach funkcji zapobiegawczej paktu stabilności i wzrostu. Konkluzje Rady z dnia 12 lutego 2013 r. w sprawie rocznej analizy wzrostu gospodarczego i w sprawie sprawozdania przedkładanego w ramach mechanizmu ostrzegania, konkluzje Rady z dnia 15 lutego $2013 \mathrm{r}$. w sprawie kształcenia, konkluzje Rady z dnia 28 lutego 2013 r. w sprawie wskazówek politycznych dotyczących polityki zatrudnienia i polityki społecznej oraz konkluzje Rady z dnia 5 marca 2013 r. w sprawie jakości wydatków publicznych.

5. Konsolidacja fiskalna i przywrócenie stabilności finansowej muszą iść w parze $z$ dobrze skonstruowanymi reformami strukturalnymi, których celem jest wspieranie trwałego wzrostu, zatrudnienia i konkurencyjności, oraz z korektą zakłóceń równowagi makroekonomicznej. W tym kontekście Rada Europejska przypomina, jak ważne jest przesunięcie obciążenia podatkowego z pracy na inne obszary - w stosownych przypadkach i przy uznaniu kompetencji państw członkowskich w tej dziedzinie - jako sposobu zwiększania szans na zatrudnienie i konkurencyjności.

${ }^{1}$ Konkluzje Rady z dnia 12 lutego 2013 r. w sprawie rocznej analizy wzrostu gospodarczego i w sprawie sprawozdania przedkładanego w ramach mechanizmu ostrzegania, konkluzje Rady z dnia 15 lutego 2013 r. w sprawie ksztalcenia, konkluzje Rady z dnia 28 lutego 2013 r. w sprawie wskazówek politycznych dotyczących polityki zatrudnienia i polityki społecznej oraz konkluzje Rady z dnia 5 marca 2013 r. w sprawie jakości wydatków publicznych. 
6. W kontekście wyzwań stawianych przez konsolidację fiskalną ważne jest zapewnienie, aby wszyscy ponosili przypadającą na nich część obciążeń podatkowych. Potrzebne są zatem wzmożone działania na rzecz poprawy skuteczności ściagania podatków i zwalczania uchylania się od opodatkowania, w tym poprzez umowy z państwami trzecimi w sprawie opodatkowania dochodów z oszczędności i szybkie postępy w zwalczaniu problemu oszustw związanych z VAT. Konieczna jest ścisła współpraca z OECD i grupą G-20 w celu opracowania uzgodnionych na szczeblu międzynarodowym standardów służących zapobieganiu erozji podstawy opodatkowania i przenoszeniu zysków. UE będzie koordynowała swoje stanowiska w tym celu. Należy poczynić postępy w pracach nad otwartymi dossier dotyczącymi podatków, takimi jak wniosek w sprawie opodatkowania energii, wniosek w sprawie wspólnej skonsolidowanej podstawy opodatkowania osób prawnych oraz wniosek w sprawie przeglądu dyrektywy o opodatkowaniu dochodów z oszczędności. Rada Europejska odnotowuje postępy prac w zakresie wzmocnionej współpracy w dziedzinie podatku od transakcji finansowych.

7. Jeżeli chodzi o działania podejmowane na szczeblu UE, trzeba kontynuować pełne i natychmiastowe wdrażanie wytycznych uzgodnionych w ostatnich miesiącach przez Radę Europejską, w szczególności w Pakcie na rzecz wzrostu gospodarczego i zatrudnienia; należy przy tym wykorzystać w szczególności potencjał zielonej gospodarki dla wspierania wzrostu i konkurencyjności. Niedawne podniesienie kapitału EBI o $10 \mathrm{mld}$ euro pozwoli temu bankowi pożyczyć dodatkową kwotę $60 \mathrm{mld}$ euro na rzecz wspierania wzrostu i zatrudnienia; wraz z Europejskim Funduszem Inwestycyjnym pomoże to uruchomić projekty o wartości do $180 \mathrm{mld}$ euro w latach 2013-2015. Rada Europejska oceni realizację wspomnianego paktu w czerwcu, kładąc szczególny nacisk na środki służące tworzeniu miejsc pracy i na pobudzenie finansowania gospodarki w odniesieniu do szybko działających środków prowzrostowych. W tym względzie Komisja, wraz z EBI, złoży w czerwcu sprawozdanie na temat możliwości i ukierunkowanych priorytetów, które należy określić, w szczególności w odniesieniu do infrastruktury, efektywności energetycznej i efektywnej gospodarki zasobami, gospodarki cyfrowej, badań i innowacji oraz małych i średnich przedsiębiorstw.

8. Pilnym zadaniem jest ukończenie i wdrożenie ram lepszego zarządzania gospodarczego. Nowe przepisy dotyczące nadzoru fiskalnego i makroekonomicznego (,sześciopak”, „dwupak” i traktat o stabilności, koordynacji i zarządzaniu) muszą zostać w pełni wykorzystane. W szczególności należy przeprowadzić wszystkie niezbędne prace przygotowawcze, aby zapewnić efektywne stosowanie tych nowych przepisów od początku krajowych cykli budżetowych w 2013 roku.

9. Dziś Rada Europejska kładzie szczególny nacisk na następujące kwestie:

a) najważniejszym wyzwaniem społecznym, przed którym stoimy, jest rozwiązanie problemu bezrobocia. Aktywne polityki społeczne oraz zatrudnienia i rynków pracy wymagają zatem priorytetowego potraktowania i szczególnej uwagi w obecnym kontekście; rangę specjalnego priorytetu trzeba nadać propagowaniu zatrudnienia młodzieży. Systemy kształcenia i szkolenia muszą działać lepiej, zapewniając młodym ludziom właściwe umiejętności i skuteczniej łącząc świat pracy ze światem edukacji. Po tym jak Rada Europejska osiagnęła w lutym 2013 roku porozumienie w sprawie Inicjatywy na rzecz zatrudnienia ludzi młodych, Komisja przedstawiła wnioski - w kontekście toczących się negocjacji w sprawie rozporządzenia o Euro- 
pejskim Funduszu Społecznym - dotyczące technicznych dostosowań, które umożliwią pełne uruchomienie wspomnianej inicjatywy z dniem 1 stycznia 2014 r. Do tego czasu państwa członkowskie będą mogły korzystać ze środków finansowych dostępnych w obecnym okresie programowania w ramach wszystkich odpowiednich funduszy strukturalnych, aby przyczynić się do zwalczania bezrobocia ludzi młodych. W związku z tym Rada Europejska z zadowoleniem przyjmuje starania Komisji mające na celu dalsze korzystanie z wyników współpracy z państwami członkowskimi, w których poziomy bezrobocia ludzi młodych są najwyższe. Porozumienie osiagnięte w Radzie w dniu 28 lutego w sprawie gwarancji dla młodzieży pomoże zapewnić wszystkim młodym ludziom poniżej 25 roku życia otrzymanie dobrej jakości oferty zatrudnienia, dalszego kształcenia, przygotowania zawodowego lub stażu w ciągu czterech miesięcy od uzyskania statusu osoby bezrobotnej lub od zakończenia kształcenia formalnego; porozumienie to powinno zostać szybko wdrożone, również przy wykorzystaniu wsparcia w ramach Inicjatywy na rzecz zatrudnienia ludzi młodych. Należy także bardziej ogólnie kontynuować prace na rzecz pakietu dotyczącego zatrudnienia, w tym w zakresie zatrudnienia znacznie większej liczby kobiet, zmniejszenia długotrwałego bezrobocia oraz zapewnienia pełnego udziału pracowników w starszym wieku. Podstawowe znaczenie ma pokonanie społecznych skutków kryzysu oraz zwalczanie ubóstwa i wykluczenia społecznego:

b) jednym z kluczowych motorów wzrostu i zatrudnienia pozostaje jednolity rynek. W tym kontekście Rada Europejska zwraca się do państw członkowskich o pełne uwzględnienie zaleceń zawartych w sprawozdaniu Komisji na temat stanu integracji jednolitego rynku i z zadowoleniem przyjmuje fakt, że Komisja zamierza włączać takie sprawozdania do przyszłych rocznych analiz wzrostu gospodarczego. Jednym z podstawowych priorytetów jest szybkie zakończenie prac nad wszystkimi wnioskami określonymi w Akcie o jednolitym rynku I, w szczególności jeżeli chodzi o takie kluczowe kwestie jak rachunkowość, kwalifikacje zawodowe, zamówienia publiczne, delegowanie pracowników oraz identyfikacja elektroniczna i podpis elektroniczny, mając na celu pobudzenie konkurencyjności, pogłębienie jednolitego rynku i zniesienie nieuzasadnionych barier. Komisja przedstawi bezzwłocznie pozostałe wnioski określone w Akcie o jednolitym rynku II z myślą o ich szybkim przeanalizowaniu, tak aby mogły one zostać przyjęte przed końcem obecnej kadencji. Pilnym zadaniem jest także poprawa wdrażania wszystkich przepisów dotyczących jednolitego rynku, w tym dyrektywy usługowej, w szczególności przez rygorystyczną wzajemną ocenę oraz szybkie działania służące usunięciu nieuzasadnionych barier. Rada Europejska będzie dalej poddawać wszystkie te kwestie regularnym przeglądom;

c) wymagane są dalsze działania mające na celu zmniejszenie ogólnego obciążenia regulacyjnego na szczeblach unijnym i krajowym, przy czym należy stale uwzględniać potrzebę właściwej ochrony konsumentów i pracowników. W świetle niedawnych komunikatów Komisji państwa członkowskie i Komisja powinny kontynuować prace nad inteligentnymi regulacjami, kładąc szczególny nacisk na potrzeby małych i średnich przedsiębiorstw. Państwa członkowskie zwrócą szczególną uwagę na unikanie dodatkowych obciążeń we wprowadzaniu prawodawstwa UE w życie. 
Rada Europejska z zadowoleniem przyjmuje niedawne sprawozdanie Komisji dotyczące najbardziej obciążających uregulowań dla małych i średnich przedsiębiorstw i oczekuje, że do czerwca otrzyma wstępne konkretne wnioski służące realizacji uwag zawartych w tym sprawozdaniu. Komisja będzie monitorowała postępy za pomocą tabeli wyników dotyczących małych i średnich przedsiębiorstw. Zapewni również sprawną i skuteczną realizację programu sprawności i wydajności regulacyjnej (REFIT), zwłaszcza przez szybkie określenie obszarów regulacyjnych i elementów prawodawstwa charakteryzujących się największym potencjałem w zakresie uproszczenia przepisów i zmniejszenia kosztów regulacyjnych. Rada Europejska oczekuje, że jesienią otrzyma pierwsze wnioski w sprawie uproszczenia i zmniejszenia obciążeń regulacyjnych. Rada Europejska odnotowuje, że Komisja przedstawi - jako część swojego rocznego programu prac - wykaz rozpatrywanych wniosków, które mają zostać wycofane. Z myślą o zmniejszeniu obciążeń wynikających z uregulowań i pobudzeniu konkurencyjności zachęca Komisję, aby skorzystała z programu REFIT w celu określenia i zaproponowania jesienią przeznaczonych do wycofania uregulowań, które nie są już przydatne, i aby kontynuowała konsolidację istniejącego prawodawstwa w ramach swoich prac nad uproszczeniem.

10. W nadchodzących miesiącach Rada Europejska przeprowadzi szereg dyskusji tematycznych na temat sektorowych i strukturalnych aspektów, które mają kluczowe znaczenie dla wzrostu gospodarczego i europejskiej konkurencyjności. Dyskusje te będą także stanowić wkład w przyszłoroczną debatę na temat strategii „Europa 2020” oraz w przegląd postępów w realizacji jej zasadniczych celów. Z myślą o tych dyskusjach wzywa do prowadzenia prac przygotowawczych przy nadaniu priorytetu następującym kwestiom:

a) energia (maj 2013 roku): prowadzone są prace nad dokończeniem tworzenia wewnętrznego rynku energii oraz nad wzajemnymi powiązaniami z europejskimi rynkami energii. Po 2015 roku żadne państwo członkowskie UE nie powinno pozostawać odizolowane od europejskich sieci gazowych i elektrycznych. Europa potrzebuje inwestycji w nowoczesną infrastrukturę energetyczną; należy także rozwiązać problem wysokich cen energii, które szkodzą konkurencyjności;

b) innowacje (październik 2013 roku): Rada Europejska oczekuje przedstawienia przez Komisję sprawozdania z postępów prac w zakresie europejskiej przestrzeni badawczej, a także komunikatu na temat stanu Unii innowacji za rok 2012, w tym jednolitego wskaźnika innowacyjności, na czas przed zaplanowanymi dyskusjami na ten temat;

c) agenda cyfrowa i inne usługi (październik 2013 roku): Rada Europejska odnotowuje, że Komisja zamierza na długo przed październikowymi dyskusjami przedstawić sprawozdanie na temat stanu prac i utrzymujących się przeszkód, którymi należy się zająć, aby zapewnić ukończenie tworzenia w pełni funkcjonującego jednolitego rynku cyfrowego do 2015 roku, a także konkretnych środków służących jak najszybszemu utworzeniu jednolitego rynku technologii informacyjno-komunikacyjnych;

d) obrona (grudzień 2013 roku): w tym kontekście Rada Europejska przyjrzy się także sposobom rozwinięcia bardziej zintegrowanej, innowacyjnej i konkurencyjnej europejskiej bazy technologiczno-przemysłowej sektora obronnego;

e) konkurencyjność przemysłowa i polityka przemysłowa (czerwiec 2013 roku i luty 2014 roku): podkreślając, jak ważne jest, by Europa stała się bardziej konkurencyj- 
na jako miejsce produkcji i inwestycji, Rada Europejska oczekuje dalszych działań w następstwie niedawnych komunikatów Komisji dotyczących polityki przemysłowej i poszczególnych sektorów przemysłowych, a także terminowego przedstawienia przez Komisję dalszego wkładu w tę dyskusję: sprawozdania na temat europejskiej konkurencyjności, sprawozdania z realizacji priorytetów polityki przemysłowej oraz wniosków z przeglądu jednolitego rynku produktów przemysłowych.

\section{Pogłębienie UGW}

11. Rada Europejska podsumowała bieżące prace nad czterema aspektami określonymi w swoich konkluzjach z grudnia 2012 roku w sprawie pogłębienia UGW. Wszelkim nowym krokom w kierunku wzmocnienia zarządzania gospodarczego będą musiały towarzyszyć dalsze działania na rzecz zwiększenia legitymacji i rozliczalności.

12. Pilnie potrzebne są postępy w kierunku bardziej zintegrowanych ram finansowych, tak aby przywrócić normalne kredytowanie, zwiększyć konkurencyjność i ułatwić wprowadzenie niezbędnych korekt gospodarczych. W nawiązaniu do postępów poczynionych w zakresie nowych zasad dotyczących wymogów kapitałowych dla banków należy szybko rozwiązać pozostałe nierozstrzygnięte kwestie techniczne, tak aby umożliwić osiagnięcie ostatecznego porozumienia do końca miesiąca. Priorytetem jest zakończenie w najbliższych tygodniach procesu ustawodawczego dotyczącego jednolitego mechanizmu nadzorczego.

13. Rada Europejska przypomina, że należy bezwzględnie przerwać błędne koło, w jakim znalazły się banki i rządy. W myśl ustaleń z grudnia 2012 roku należy w pierwszym półroczu 2013 roku jak najszybciej uzgodnić ramy operacyjne, w tym definicję aktywów odziedziczonych, tak by w momencie utworzenia skutecznego jednolitego mechanizmu nadzorczego Europejski Mechanizm Stabilności miał - w drodze zwykłej decyzji - możliwość bezpośredniego dokapitalizowywania banków. Do czerwca 2013 roku trzeba osiagnąć porozumienie co do dyrektywy w sprawie naprawy oraz restrukturyzacji i uporządkowanej likwidacji banków oraz dyrektywy w sprawie systemów gwarancji depozytów, zapewniając przy tym sprawiedliwą równowagę między krajami pochodzenia a krajami przyjmującymi. Komisja zamierza przekazać do lata 2013 roku wniosek ustawodawczy w sprawie jednolitego mechanizmu restrukturyzacji i uporządkowanej likwidacji dla krajów uczestniczących w jednolitym mechanizmie nadzorczym: wniosek ten będzie analizowany na zasadzie priorytetu, tak aby móc go przyjąć podczas obecnej kadencji Parlamentu. Mechanizm ten powinien zapewnić skuteczne ramy restrukturyzacji i uporządkowanej likwidacji instytucji finansowych przy zapewnieniu ochrony podatników w kontekście kryzysów bankowych, opierać się na wkładach wnoszonych przez sam sektor finansowy oraz obejmować odpowiednie i skuteczne mechanizmy ochronne, zgodnie z konkluzjami z grudnia 2012 roku. Integralność jednolitego rynku będzie w pełni przestrzegana; zapewnione zostaną także równe warunki działania państw członkowskich uczestniczących w jednolitym mechanizmie nadzorczym i tych, które w nim nie uczestniczą.

14. Rada Europejska odnotowuje przyjęcie zasad organizacji prac na szczytach strefy euro i z zadowoleniem przyjmuje fakt, że zasady te mają służyć poprawie jakości zarządzania strefą euro, przy zachowaniu integralności Unii Europejskiej jako całości, 
jak stwierdzono w szczególności w stosownych postanowieniach Traktatu o stabilności, koordynacji i zarządzaniu w unii gospodarczej i walutowej ${ }^{1}$.

\section{POZOSTALE KWESTIE}

15. Rada Europejska przeprowadziła wymianę poglądów na temat stosunków UE $\mathrm{z}$ jej partnerami strategicznymi.

1 Niderlandy zgłosily zastrzeżenie parlamentarne do tego punktu. 